\title{
Sakarya Üniversitesi Tıp Fakültesi Dönem I,II,III Öğrencilerinde Sağlıklı Yaşam Davranışları ve iliş̧kili Faktörlerin incelenmesi
}

\section{Study of Healthy Life Behaviors and Related Factors In Students In Sakarya University Medical Faculty Classes of I, II, III}

\author{
Elif Köse', Bahar Güçiz Doğan², Hasan Çetin Ekerbiçer³ \\ ' ASakarya Üniversitesi, Eğitim ve Araştırma Hastanesi, Sakarya \\ ${ }^{2}$ Hacettepe Üniversitesi Tıp Fakültesi, Halk Sağlığı AD, Ankara \\ ${ }^{3}$ Sakarya Üniversitesi Tıp Fakültesi, Sakarya
}

Yazışma Adresi / Correspondence:

Elif Köse

Sakarya Üniversitesi, Eğitim ve Araştırma Hastanesi, Sakarya

T: +90 (264) 4445400 E-mail: elifyldzkose@hotmail.com

Geliş Tarihi / Received : 16.01.2018 Kabul Tarihi / Accepted : 09.03.2018

\footnotetext{
Öz

Amaç Sağıklı yașam biçimi, bireyin sağlığını etkileyebilecek davranıșlarını kontrol edebilmesi, günlük aktivitelerini düzenlemesi, kendi sağlık durumuna uygun davranışları seçmesi olarak tanımlanmaktadır. Bu araştırmanın amacı geleceğin sağlık çalışanı olan tıp fakültesi öğrencilerinin sağıłklı yaşam davranışlarını ve ilişkili etmenleri incelemektir. ( Sakarya Tıp Dergisi 2018, 8(1):20-29)

Gereç ve Araștırmanın evrenini Sakarya Üniversitesi Tıp Fakültesi Dönem I, II, III öğrencileri (321 kişi) olușturmaktadır. Evrenin \%61,1'ine (198

Yöntem kişi) ulassıldığı bu çalıșma tanımlayıcı tipte epidemiyolojik bir arasstırmadır. Arasşırmanın değiskenleri, öğrencilerin bazı sosyodemografik özellikleri, bazı alışkanlıkları, risk alma davranışları ve Sağıkıı Yaşam Biçimi Davranışları Ölçeği II (SYBDÖ-2) puanıdır. Veriler SPSS 21.0 windows paket programı kullanılarak uygun istatistik testlerle değerlendirilmiştir.

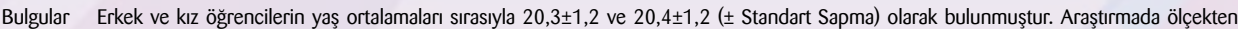

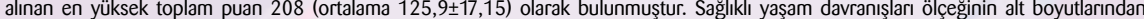
sadece fiziksel aktivite alt boyutu puanı erkeklerde, kızlardan yüksek çıkmışır $(p=0,001)$. Sosyoekonomik durum algısı iyileştikçe sağıkkı yaşam davranışları ölçeğinden alınan puan artmaktadır $(p=0,006)$.

Sonuç Araştırmaya katılan öğrenciler bazı sağıklı yaşam davranışları açısından eksik olduğu görülmüştür. Beslenme, fiziksel aktivite, tütün kullanımı, diş fırçalama, emniyet kemeri takma konusunda öğrencilerin bilgilendirilmesi, okul yemekleri, fiziksel aktivite alanları, aşılama konusunda yönetimle is birliği içerisinde olarak müdahaleler planlanabilir.

Anahtar Sağılklı yașam davranışları; sağlıklı yaşam biçimi ölçeği II; öğrenci; risk alma davranışı

Abstract

Objective Healthy lifestyle is defined as the ability to control behaviors that may affect an individual's health, to organize daily activities, and to select behaviors appropriate to health status. The purpose of this study is to examine the healthy lifestyle behaviors and related factors of medical faculty students who are health professionals. ( Sakarya Med J 2018, 8(1):20-29).

Materials and The universe of the research is composed of the students (321 persons) of Sakarya University Faculty of Medicine Classes of I, II, III. This

Methods study, in which $61.1 \%$ (198 people) of the universe were reached, is a descriptive epidemiological study. The variables of the study were some sociodemographic characteristics, some habits, risk taking behaviors and Healthy Lifestyle Behavior Scale II (SYBRS-2) scores of the students. The data were evaluated with appropriate statistical tests using SPSS 21.0 windows package program.

Results The mean age of male and female students was found to be $20.3 \pm 1.2$ and $20.4 \pm 1.2$ ( \pm Standard Deviation). The highest total score was 208 (mean 125,9 $\pm 17,15$ ) in the survey,

Only the scores of physical activity subscale were higher in males than in females $(p=0.001)$ from the subscales of healthy life behaviors scale. As the socioeconomic status perception improves, the score of healthy lifestyle scale increases $(p=0.006)$.

Conclusions: Students participating in the study were found to be deficient in some healthy living behaviors.

Interventions can be planned in cooperation with management on nutrition, physical activity, tobacco use, brushing teeth, informing students about wearing safety belts, school meals, physical activity areas, vaccination.

Key words: Healthy life behaviors; healthy lifestyle scale II; student; risk taking behavior 
Sakarya TIp Dergisi

2018;8(1):20-29

\section{Giriş}

Sağıkkı yaşam biçimi, bireyin sağlığını etkileyebilecek davranışlarını kontrol edebilmesi, günlük aktivitelerini düzenlemesi, kendi sağlık durumuna uygun davranışları seçmesi olarak tanımlanmaktadır ${ }^{1}$. Birçok metabolik hastalıktan kaçınmanın temelinde yer alan doğru beslenme, fiziksel aktivite ve stresten kaçınma önde gelen sağlıklı yaşam davranışlarıdır. Günümüzde kardiyovasküler hastalıklar, kanser, kalp hastalığı, hipertansiyon ve diyabet gibi kronik hastalıklardaki morbidite ve mortalitenin yaşam biçimi değişiklikleri ile önemli ölçüde azaltılabildiği bilinmektedir ${ }^{2,3,4}$.

Sağlık çalışanları, mesleki sorumlulukları ve sosyal rolleri gereği rol model olma ve sağlık eğitimi yönünden hizmet verdikleri grubu etkileme özelliğine sahiptir ${ }^{5}$.

Sağlıklı yaşam biçimi davranışlarının geliştirilmesi ve tutum haline getirilmesinde, üniversite eğitimi süreci büyük öneme sahiptir. Sağıkkı yaşam davranışları fiziksel aktivite ile sınırlı olmayıp stres yönetimi, sağlık sorumluluğu, beslenme de sağlıklı yaşam davranışı olarak kabul edilebilir. Böylece hem gençlik döneminde kazanılması gereken davranışlar bir yaşam biçimi haline dönüştürülmüş, hem de geleceğin hekimleri olarak sağlı̆ın fiziksel, sosyal ve ruhsal iyilik hali kavramlarını birey olarak da hayata geçirme tecrübesi elde edilmiş olur. Sağlığın korunması ve geliştirilmesi için görev alacak hekimleri yetiştiren tıp fakültelerinde okuyan öğrenciler IV. sınıftan başlamak üzere hastalar ile etkileşim içerisinde olmaktadır. Dolayısıyla tıp öğrencileri, uyguladıkları sağlıklı yaşam davranışlarını çevresine yansıtmakta, hastaların tedavilerinin yanı sıra onlar için de rol model olmaktadırlar. Bu araştırmanın amacı, geleceğin sağlık çalışanları olacak olan tıp fakültesi öğrencilerinin sağlıklı yaşam davranışlarını ve ilişkili etmenleri belirlemektir.

\section{Yöntem}

Tanımlayıcı tipte olan bu araştırmanın evreni Sakarya Üniversitesi Tıp Fakültesi Dönem I (138 kişi), Dönem II (115 kişi) ve Dönem III (71 kişi) öğrencileri olmak üzere toplam 324 kişiden oluşmaktadır. Araştırmada örneklem seçilmemiş olup, veri toplama süresi içinde evrenin tamamına ulaşılmaya çalışılmış fakat ancak \%61,1'ine (198 kişi) ulaşılabilmiştir. Dönem I, II, III derslikleri yakın olduğundan dolayı veri kalitesi açısından, veri toplama süresi üç gün olarak belirlenmiş ve sadece bu günlerde okulda olan ve araştırmaya katılmayı kabul eden öğrenciler araştırmaya dâhil edilmiştir. Sınav dönemi oluşu da katılımın az olmasının nedenlerindendir.

Anket formunda yaş cinsiyet gibi bazı sosyodemografik özellikler, diş fırçalama gibi bazı alışkanlıklar ve emniyet kemeri takma gibi bazı risk alma davranışları ile ilgili 38 soru ve Sağlıklı Yaşam Biçimi Davranışları Ölçeği II (SYBDÖ-2) (52 soru) yer almıştır.

Walker tarafından 1987 yılında geliştirilen sağlıklı yaşam biçimi davranışları ölçeğinin ilk versiyonu 48 madde ve altı faktörden oluşmaktadır ${ }^{6}$. Ölçek 1996 yılında revize edilmiş ve Sağlıklı Yaşam Biçimi Davranışları Ölçeği II olarak adlandırılmıştır ${ }^{7}$ Ölçek 52 madde ve altı faktörden oluşmaktadır. Bunla; manevi gelişim, kişilerarası ilişkiler, beslenme, fiziksel aktivite, sağlık sorumluluğu ve stres yönetimidir. Ölçeğin geliştirilme aşamasında veriler 18-92 yaş arasındaki 712 bireyden elde edilmiştir. Ölçeğin güvenirlik katsayısı olan Cronbach Alpha değeri toplam ölçek için 0,94 olup, altı alt faktör için 0,79-0,87 arasında değişim göstermektedir. 
miş; ölçeğin Cronbach Alpha güvenirlik katsayısı 0,94 olarak bulunmuştur. Ölçeğin alt boyutlarının Cronbach Alpha değerleri 0,79-0,87 arasında değişmektedir. Ölçeğin genel puanı sağıklı yaşam biçimi davranışları puanını vermektedir. Ölçeğin tüm maddeleri olumludur. Ölçek, hiçbir zaman (1 puan) ile düzenli olarak (4 puan) arasında dörtlü likert olarak derecelendirilerek puanlanmıştır. Ölçeğin tamamı için en düşük puan 52, en yüksek puan 208'dir'.

Bu çalışmanın sonuçları, Sakarya Üniversitesi'nda 2016-2017 eğitim-öğretim ylında öğrenim gören ve yalnızca çalışma kapsamına alınan Tıp Fakültesi öğrencilerinin bildirimleri ile sınırıdır. Araştırmaya katılan öğrenciler kısıtlı sayıda olduğundan dolayı evrenin tamamı temsil edilememektedir. Araştırma formunu uygulayabilmek için Tıp Fakültesi Dekanlığ’ndan ve Sakarya Üniversitesi Girişimsel Olmayan Araştırmalar Etik Kurulu’ndan izin alınmıştır. Veri toplamaya başlamadan önce çalışma hakkında öğrencilere bilgi verilmiş, isim soy isim alınmamıştır, anket formunu doldurmuş olmaları onam verdikleri şeklinde değerlendirilmiştir. Anketler sınıf dersleri başında veya sonunda dağıtılarak gözlem altında doldurulmuştur.

Verilerin analizinde değişkenlerin yüzde dağılımları alınmış, sürekli değişkenler için merkezi ve yaygınlık ölçütleri (ortalamaさstandart sapma) hesaplanmıştır. Değişkenlerin normal dağlıma uygunluğu görsel (histogram ve olasılık grafikleri) ve analitik yöntemler (Kolmogorov Smirnov testi) kullanılarak incelenmiştir. Bağımlı ve bağımsız değişkenler arası ilişkiler ki-kare testi, Kruskal Wallis testi, Mann Whitney U testi kullanılarak değerlendirilmiştir. i̇statistiksel analizler SPSS 21.0 for Windows paket programı kullanılarak yapılmış, $p<0.05$ anlamlı olarak kabul edilmiştir.

\section{Bulgular}

Araştırmaya katılan 1. 2. ve 3. dönem erkek öğrencilerin dağıııı sırasıyla \%44,6, \%36,1, \%19,3 olarak saptanmıştır. Araşıımaya katılan öğrencilerin \%47,0'ı hayatının ilk 12 yılını geçirdiği yerin kent özelliğinde olduğunu belirtmiştir. Öğrencilerin \%49,4'ü yurtta, \%27,7'si evde ailesi ya da akrabasılla, \%16,9'u arkadaşları ile birlikte evde, \%6,0'ı evde tek başına yaşadığını belirtmiştir. Araştırmaya katılan öğrenciler 18-26 yaş aralı̆ında olup, erkek ve kız öğrencilerin yaş ortalamaları

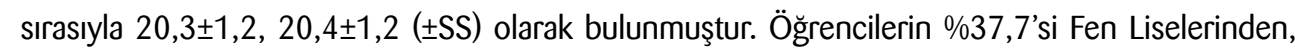
\%48,4'ü Anadolu Lisesi ve Kolejlerden mezun olduğunu belirtmiştir. Her iki cinsiyette de yaygın aile yapısı çekirdek aile tipidir $(\% 87,0)$.

Araştırmaya katılan erkek öğrencilerin \%4,8'inin, kız öğrencilerin \%10,4'ünün kronik hastalığı mevcut olup; erkeklerin \%65,1'i, kızların \%59,1'i şikayeti olmadan kontrol amaçlı doktora gittiğini belirtmiştir $(p>0,05)$.

Her iki cinsiyetteki öğrencilerin yaklaşık dörtte üçü şimdiye dek hiç diş hekimine gitmediklerini belirtmişlerdir ( $p>0,05)$. Erkek öğrencilerin \%42,2'si, kız öğrencilerin \%79,2'si dişlerini günde en az iki kez fırçaladıklarını ifade etmişlerdir ( $\rho<0,001$, Tablo 1).

Araştırmaya katılan erkek öğrencilerin \%36,8'i, kız öğrencilerin \%13,1'i arada sırada ya da halen sigara içtiğini $(p=0,015)$; erkek öğrencilerin \%24,1'i, kız öğrencilerin \%10,4'ü arada sırada ya da halen alkollü içki tükettiğini belirtmiştir $(\mathrm{p}=0,027)$. Araştırmaya katılan erkek öğrencilerin beşte birinin $(\% 19,8)$ kız öğrencilerin dörtte birinin $(\% 27,4)$ günde en az bir öğünü atladığı saptanmış-
Sakarya Tip Dergisi 2018;8(1):20-29

KösE ve Ark. Dönem I,II,III Ögrencilerinde Sağ̣ılkı Yașam Davranışarı Ve ilişkili Faktörlerin Incelenmesi 


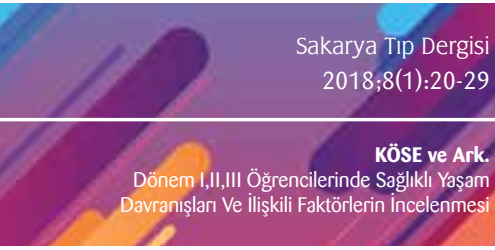

tır $(p=0,188)$. Erkek öğrencilerin daha çok $(\% 64,1)$ sabah kahvaltısını, kız öğrencilerin daha çok $(\% 55,6)$ öğle yemeğini atladığı tespit edilmiştir. Erkek öğrenciler arasında Hepatit A ve B aşısı olma açısından hiç aşısı olmayanların yüzdesi \%31,1 iken, kız öğrencilerde \%11,1'dir ( $p=0,009)$.

Tablo 1. Sakarya Üniversitesi Tup Fakültesi Dönem I, II, III öğrencilerinin cinsiyete göre diş hekimine gitme ve diş fırçalama alşkanlıkları (Sakarya, 2017)

\begin{tabular}{|l|c|c|c|c|c|}
\hline \multirow{2}{*}{ Diş sağı̆̆ğı alışkanlıklarına dair bazı özellikler } & \multicolumn{2}{|c|}{ Erkek $(\mathrm{n}=83)$} & \multicolumn{2}{|c|}{ Kız $(\mathrm{n}=115)$} & \multirow{2}{*}{$\mathrm{P}$} \\
\cline { 2 - 4 } & Sayı & Yüzde & Sayı & Yüzde &
\end{tabular}

Diş hekimine gitme sıklı̆̆

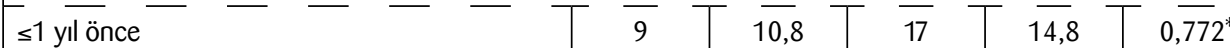

$>1$ yll önce

Yakınması olduğunda

Hiç gitmemis

\begin{tabular}{l|c|c|c}
10,8 & 17 & 14,8 \\
2 & 2,4 & 1 & 0,9
\end{tabular}

Diş fırçalama alışkanlı̆̆

Günde üç kez

Günde iki kez

Günde bir kez

Arada sırada

Hiç

\begin{tabular}{l|l|l|l}
8 & 9,6 & 11 & 14,8
\end{tabular}

\begin{tabular}{l|l|l|l}
64 & 77,1 & 86 & 74,8 \\
\hline
\end{tabular}

"Ki kare analizi, kategoriler "gitmiş" ve "gitmemiş" şeklinde gruplanarak yapılmıștır.

**Ki kare analizi, kategoriler "günde iki-üç kez", "günde bir kez", "arada sırada-hiç" şeklinde gruplanarak yapılmıştır.

Erkek öğrencilerin \%42,2'si, kız öğrencilerin $\% 27,8^{\prime}$ i ehliyetleri bulunduğunu ( $\left.\rho=0,035\right)$; araba kullanırken erkek öğrencilerin \%5,6'sı hiçbir zaman, \%22,2'si bazen, kız öğrencilerin \%11,1'i bazen emniyet kemeri takmadığını belirtmişlerdir $(p=0,049)$. Erkek öğrencilerin $\% 62,2$ 'si, kIz öğrencilerin \%52,6'sı yolcu olarak arka koltukta emniyet kemeri takmadıklarını ifade etmişlerdir ( $p=0,021$, Tablo 2$)$.

Araştırmaya katılan öğrencilerin ehliyetleri olma durumuna göre araba kullanma durumu değerlendirildiğinde . ehliyeti olmayan 10 kişinin araba kullandığı belirlenmiştir $(p<0,001)$.

Araştırmaya katılan erkek öğrencilerin \%21,0'ının, kız öğrencilerin \%8,7'sinin beden kitle indeksi 25,0 ve üzerindedir. Erkek öğrencilerin \%9,6'sı, kız öğrencilerin \%2,6'sı 6 saatten az uyumaktadır. Erkek öğrencilerin yarısı, kız öğrencilerin beşte biri günde iki litreden az su içmektedir. Su içme davranışı cinsiyet açısından farklı olduğu istatistiksel açıdan da anlamlıdır $(p<0,001)$.

Araştırmada kullanılan Sağlıklı Yaşam Biçimi Davranışları Ölçeği II (SYBDÖ-2)'den alınabilecek en yüksek toplam puan 208 olup, araştırmada alınan toplam puan ortalaması 125,9ะ17,2 olarak bulunmuştur. Araştırmaya katılan erkek öğrencilerin toplam ölçek puanı kız öğrencilerden yüksek olsa da fark istatistiksel olarak anlamlı değildir $(t=0,869, p=0,386)$. SYBDÖ-2'nin alt boyutlarından sadece fiziksel aktivite alt boyutu araştırmaya katılan öğrenciler arasında erkeklerde kızlardan istatistiksel açıdan da anlamlı olarak daha yüksek çıkmışır ( $p=0,001$, Tablo 3 ).

Araştırmaya katılan öğrencilerin toplam SYBDÖ-2 puanının sınıflara göre de benzer olduğu görülmüştür $(p=0,740)$. Araştırmaya katılan öğrencilerin SYBDÖ-2 puanı mezun olduğu lise tipine göre de değişmemektedir $(p=0,945)$. 
Araştırmaya katılan öğrencilerin SYBDÖ-2 puanının sosyoekonomik durumunu "iyi” olarak algılayanlarda yüksek iken, "kötü" olarak alglayanlarda düşük olduğu saptanmıştır. ( $\mathrm{p}=0,006$, Tablo 4). Sosyoekonomik durum algısı iyileştikçe SYBDÖ-2'nin alt boyutlarından "sağlık sorumluluğu", "beslenme" ve "manevi gelişim" alanlarından da daha yüksek puan alındığı görülmüştür; bu durum istatistiksel olarak da anlamlıdır (sırasıyla $p=0,031 ; p=0,012 ; p=0,018$, Tablo 5).

Tablo 2. Sakarya Üniversitesi Tip Fakültesi Dönem I,II, III öğrencilerinin trafik güvenlik kuralları ile ilgili bazı özelliklerinin cinsiyete göre dağlımı (Sakarya,2017)

\begin{tabular}{|c|c|c|c|c|c|}
\hline \multirow{2}{*}{ Trafik güvenlik kuralları ile ilgili bazı özellikler } & \multicolumn{2}{|c|}{ Erkek } & \multicolumn{2}{|c|}{$\mathrm{Kız}$} & \multirow{2}{*}{$\rho$} \\
\hline & Sayı & Yüzde & Sayı & Yüzde & \\
\hline Ehliyetinin olma durumu & $\mathrm{n}=83$ & & $\mathrm{n}=115$ & & \\
\hline Var & 35 & 42,2 & 32 & 27,8 & 0,035 \\
\hline Yok & 48 & 57,8 & 83 & 72,2 & \\
\hline Araba kullanma durumu & $\mathrm{n}=83$ & & $\mathrm{n}=115$ & & \\
\hline Kullanıyor & 36 & 43,4 & 27 & 23,5 & 0,003 \\
\hline Kullanmıyor & 47 & 56,6 & 88 & 76,5 & \\
\hline Araba kullanırken emniyet kemeri takma durumu & $\mathrm{n}=36$ & & $n=27$ & & \\
\hline Her zaman & 17 & 47,2 & 21 & 77,8 & $0,049^{* *}$ \\
\hline Sık sık & 9 & 25,0 & 3 & 11,1 & \\
\hline Bazen & 8 & 22,2 & 3 & 11,1 & \\
\hline Hiç bir zaman & 2 & 5,6 & - & - & \\
\hline $\begin{array}{l}\text { Yolcu olarak ön koltukta emniyet kemeri takma } \\
\text { durumu }\end{array}$ & $\mathrm{n}=82$ & & $\mathrm{n}=114$ & & \\
\hline Her zaman & 34 & 41,5 & 62 & 54,4 & $0,102^{* *}$ \\
\hline Sık sık & 24 & 29,3 & 20 & 17,5 & \\
\hline Bazen & 21 & 25,6 & 28 & 24,6 & \\
\hline Hiç bir zaman & 3 & 3,7 & 4 & 3,5 & \\
\hline $\begin{array}{l}\text { Yolcu olarak arka koltukta emniyet kemeri takma } \\
\text { durumu }\end{array}$ & $\mathrm{n}=82$ & & $\mathrm{n}=114$ & & \\
\hline Her zaman & 2 & 2,4 & 11 & 9,6 & 0,021 \\
\hline Sık sık & 1 & 1,2 & 10 & 8,8 & \\
\hline Bazen & 28 & 34,1 & 33 & 28,9 & \\
\hline Hiç bir zaman & 51 & 62,2 & 60 & 52,6 & \\
\hline
\end{tabular}

Araştırmaya katılan öğrencilerin toplam SYBDÖ-2 puanı kronik hastalığı olma durumuna göre değerlendirildiğinde anlamlı bir fark görülmemiştir $(p=0,274)$.

Öğün atlamayan erkek öğrencilerde SYBDÖ-2 puanının yüksek öğün atlayanlardan yüksek olduğu görülmüştür $(p=0,041)$.Araştırmaya katılan erkek öğrencilerin SYBDÖ-2 alt boyutları puanları öğün atlama durumuna göre değerlendirildiğinde "sağlık sorumluluğu" ve "beslenme" boyutlarında anlamlı bir fark görülmektedir, öğün atlamayanların bu alt boyutlardan daha yüksek puan aldığı saptanmıștır (sırasıyla $p=0,037$ ve $p<0,001$ ). Araştırmaya katılan kız öğrencilerin SYBDÖ-2 alt boyutları puanları öğün atlama durumuna göre değerlendirildiğinde "fiziksel aktivite" alt boyutunda anlamlı bir fark görülmektedir, öğün atlayanların daha düşük puan aldığı saptanmışır $(p=0,048)$. Araştırmaya katılan öğrencilerin toplam SYBDÖ-2 puanı Hepatit A ve B aşısı yaptırma durumuna
Sakarya Tip Dergisi

$2018 ; 8(1): 20-29$

KöSE ve Ark. Dönem I,IIIIII Ögrencencilerinde Sağı̆ıkı Yasam Davranııșan Ve liliskili Faktörlerin incelenmes 


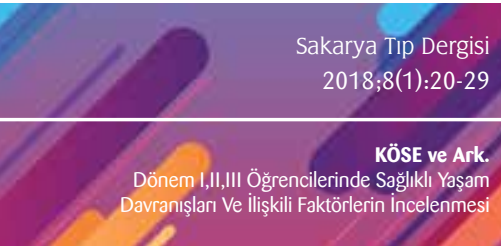

göre değerlendirildiğinde, tam aşılı olanların en yüksek, aşısız olanların en düşük puanı aldıkları görülmektedir, bu durum istatistiksel olarak da anlamlıdır $(p=0,032)$.

Tablo 3 Sakarya Üniversitesi Tıp Fakültesi Dönem I,II, III öğrencilerinin Sağlıklı Yaşam Biçimi Davranışları Ölçeği II alt ölçek puanlarının cinsiyete göre dağılımı (Sakarya, 2017)

\begin{tabular}{|l|c|c|c|c|c|}
\hline Alt ölçekler & \multicolumn{2}{|c|}{ Cinsiyet } & \multicolumn{3}{c|}{ Anlamlılk dercesi } \\
\hline & Erkek $\mathrm{n}=83$ & Kız $\mathrm{n}=115$ & Mann-Whitney U & $\mathrm{z}$ & $\mathrm{P}$ \\
\hline Sağlık sorumluluğu & 95,8 & 102,4 & 4455,0 & $-0,8$ & 0,424 \\
\hline Fiziksel aktivite & 114,8 & 88,4 & 3499,5 & $-3,2$ & 0,001 \\
\hline Beslenme & 92,8 & 104,3 & 4218,5 & $-1,4$ & 0,162 \\
\hline Manevi gelişim & 104,4 & 95,9 & 4366,5 & $-1,0$ & 0,306 \\
\hline Stres yönetimi & 101,7 & 97,9 & 4589,5 & $-0,5$ & 0,644 \\
\hline Kişiler arası ilişki & 98,9 & 99,9 & 4727,0 & $-0,1$ & 0,909 \\
\hline "Mann-Whitney U testi & \multicolumn{5}{|l}{} \\
\hline
\end{tabular}

Tablo 4. Sakarya Üniversitesi Tip Fakültesi Dönem I,II, III öğrencilerinin Sağlkkı Yaşam Biçimi

Davranışları Ölçeği II toplam puanının sosyoekonomik durum beyanına göre dağlımı (Sa-

karya, 2017)

\begin{tabular}{|l|c|c|c|c|}
\hline & \multicolumn{3}{|c|}{ Sosyoekonomik durum } & \multirow{2}{*}{$P$} \\
\cline { 1 - 3 } & ìyi $(\mathrm{n}=95)$ & Orta $(\mathrm{n}=100)$ & Kötü $(\mathrm{n}=3)$ & \\
\hline Ortalama & 112,68 & 88,01 & 65,33 & \multirow{2}{*}{0,006} \\
\cline { 1 - 3 } Ortanca & 128,0 & 123,5 & 110,0 & \\
\cline { 1 - 3 } Çeyrekler arası aralık & $119,0-141,0$ & $109,5-133,75$ & $105,0--$ & \\
\cline { 1 - 3 }${ }^{*}$ Kruskal-Wallis testi & \multicolumn{4}{|l}{} \\
\hline
\end{tabular}

Tablo 5. Sakarya Üniversitesi Tıp Fakültesi Dönem I,Il, III öğrencilerinin Sağlıklı Yaşam Biçimi Davranışları Ölçeği II'ne ait alt ölçek puanlarının sosyoekonomik durum beyanına göre dağlımı (Sakarya, 2017)

\begin{tabular}{|l|c|c|c|c|}
\hline & \multicolumn{3}{|c|}{ Sosyoekonomik durum } & \multirow{2}{*}{$p$} \\
\hline & İyi $(\mathrm{n}=95)$ & Orta $(\mathrm{n}=100)$ & Kötü $(\mathrm{n}=3)$ & \\
\hline Sağlık Sorumluluğu & 110,15 & 90,44 & 64,17 & 0,031 \\
\hline Fiziksel aktivite & 102,66 & 96,21 & 109,17 & 0,702 \\
\hline Beslenme & 110,35 & 90,93 & 41,50 & 0,012 \\
\hline Manevi gelişim & 111,44 & 88,81 & 78,00 & 0,018 \\
\hline Stres yönetimi & 107,88 & 92,57 & 65,33 & 0,099 \\
\hline Kişiler arası ilişki & 113,25 & 86,62 & 93,50 & 0,005 \\
\hline "Kruskal wallis testi & \multicolumn{4}{|l}{} \\
\hline
\end{tabular}

\section{Tartışma}

Sakarya Üniversitesi Tıp Fakültesi Dönem I, II, III öğrencilerinden erkeklerin \%51,8'i, kızların \%69,6'sı araştırmaya dâhil olmuştur. Araştırmaya katılanların yaklaşık yarısı yurtta yaşamaktadır. Araştırmaya katılan öğrenciler içinde erkeklerin \%65,1’i, kızların \%59,1’i şikayeti olmadan doktora gitmemektedir. Öğrenciler hekime genelde hasta olduklarında gitmekte, koruyucu amaçlı hekime başvurmamaktadır. Bu durum öğrencilerin sağık hizmetlerini sadece tedavi amaçlı kullandıklarını göstermektedir. Araştırmaya katılan erkek öğrencilerin \%77, 1'i, kız öğrencilerin \%74,8'i hiç diş hekimine gitmemiştir. Diş fırçalama alışkanlığının erkeklerin \%42,2'sinde, kızların \%79,2'sinde günde iki veya daha fazla kez olduğu görülmüştür. Uygun şekilde diş fırçalama alışkanlığı kızlarda erkeklerin iki katıdır. Bu durum kız öğrencilerin ağız sağlığı konusunda daha hassas olduğunu göstermek- 
tedir. Öğrencilerin dörtte üçünün diş hekimine gitmemiş olmalarının nedeni gitmedim seçeneğini işaretleyenlerin bir kısmının gitmiş olsa bile hatırlamadıklarından dolayı olabilir.

Sağlık fiziksel, çevresel, biyolojik, psikososyal çevrenin bir bileşkesidir. Sağlığın sadece biyolojik parametrelerle ölçülmesi mümkün değildir. SYBDÖ-2 birçok yönden sağlık ya da hastalığa zemin hazırlayacak etmenlerin belirlenmesi açısından önemlidir. Bu tarz kapsamlı ölçeklerle yapılan geniş çaplı araştırmalarla yöneticiler tarafından da müdahale edilmesi gereken alanları objektif olarak sunmak mümkündür. Bu araştırmada 52 soruluk Sağlıklı Yaşam Biçimi Davranışları Ölçeği (SYBDÖ-2) kullanılmıştır.

Çalışmada en yüksek 208 puan alınan SYBD-2 ölçeğinden alınan puan ortalaması 125,9 $9 \pm 17,2$ olarak bulunmuştur. Ankara'da hemşirelerde yapılan bir araştırmada aynı ortalama 122 $\pm 17,2$, Çanakkale'de Sağlık Yüksek Okulu öğrencilerinde yapılan araştırmada 122,1士19,8, Kayseri'de Meslek Yüksekokullarının Sağlık ve Sosyal Programlarında Öğrenim Gören Öğrencilerin Sağlıkı Yaşam Biçimi Davranışlarının incelendiği araştırmada sağlık alanında okuyan öğrencilerde $118,5 \pm 21$, 4, sosyal alanındaki öğrencilerde 125,3 24,0, Kırıkkale'de Sağlık Bilimleri Fakültesi'ndeki birinci

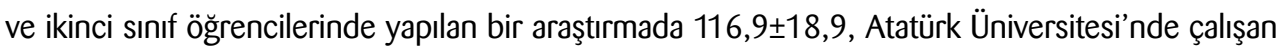
hemşirelerde121,2 $\pm 18,3$ Bandırmada bir devlet hastanesinde çalsşan hemşirelerde 125,9 916,9 , İstanbul'da bir vakıf üniversitesinde okuyan öğrencilerde 130,4 $\pm 17,1$, Ege Üniversitesi'nde ameliyathanede çalışan hemşirelerin gönülü olarak katıldığı araştırmada 116,8 16 ,3 olarak bulunmuştur ${ }^{4,9-15}$. Bu çalışmanın sonucu da diğer araştırmalarla benzerdir.

Araştırmada cinsiyete göre ölçekten alınan toplam puan ortalamaları arasında istatistiksel olarak anlamlı farklılık saptanmamışıı. Ancak erkek öğrencilerin ölçekten aldıkları toplam puan ortalaması kızlardan daha yüksektir. Hitit Üniversitesi'nde, Uludağ Üniversitesi'nde ve Malatya'da bir lisede yapılan çalışmalarda da erkeklerin SYBDÖ-2'ye göre puan ortalaması kızlardan istatistiksel olarak anlamlı derecede yüksek bulunmuştur ${ }^{16-18}$.

Araştırmaya katılan öğrencilerin SYBDÖ-2 toplam puanları yaşa göre farklılık göstermemektedir. Ancak Hatay Sağılık Meslek Yüksek Okulu'nda yapılan araştırmada yaş ile toplam SYBDÖ-2 puanları arasında anlamlı bir ilişki bulunmuştur ${ }^{19}$.

Araştırmaya katılan öğrencilerin SYBDÖ-2 toplam puanları sınıflara göre farkllılık göstermemektedir. İzmir, Manisa ve Sivas'ta üniversite öğrencilerinde yapılan çalışmalarda da sınıflar arasında SYBDÖ-2 puanları açısından anlamlı farkılık saptanmamışıı ${ }^{3,20,21}$.

Araştırmaya katılan öğrencilerde sosyoekonomik durum algısı iyileştikçe ölçekten alınan puanların daha yüksek olduğu saptanmıştır., İstanbul'da bir vakıf üniversitesinin Hemşirelik Yüksekokulu, Fen Edebiyat Fakültesi, Konservatuar, Mimarlık Fakültesi, İşletme Fakültesi ve Bilgisayar Mühendisliği bölümünde okuyan öğrencilerde ( $N=1337)$, Celal Bayar Üniversitesi Eğitim Fakültesi'nde okuyan öğrencilerde, Uludağ Üniversitesi Sağlık Yüksekokulu’nda okuyan öğrencilerde, Dokuz Eylül Üniversitesi Tıp Fakültesi'nde 2011-2012 öğretim yilında birinci sınıf öğrencilerde yapılan çalışmalarda da benzer şekilde sosyoekonomik durum algısı iyi olanların, SYBDÖ-2 ölçeğinden iyi olmayanlara göre daha yüksek puan aldıkları görülmüştür ${ }^{16-18,22}$.

Araştırmaya katılan öğrencilerin SYBDÖ-2 toplam puanları şikâyeti olmadan doktor kontrolüne gi-
Sakarya Tip Dergisi

2018;8(1):20-29

KöSE ve Ark.

Dönem I,II,III Ögrencilerinde Sağ̣̆lkı Yașam

Davranışarı Ve ilişkili Faktörlerin Incelenmesi 
Sakarya Tıp Dergisi

2018;8(1):20-29

KÖSE ve Ark.

Dönem I,II,III Öğrencilerinde Sağlkkı Yaşam Davranış̧arı Ve ilişkili Faktörlerin İncelenmes dip gitmeme durumuna göre değerlendirildiğinde , yakınması olmadan doktora giden öğrencilerin daha yüksek ölçek puanına sahip olduğu görülmüştür. Bu durum istatistiksel açıdan da anlamlıdır. Çukurova Üniversitesinde yapılan bir çalışmada da benzer şekilde yakınma olmaksızın doktor kontrolüne gidenlerin SYBDÖ-2 puan ortalaması, doktor kontrolüne hiç gitmemiş olanlardan istatistiksel olarak anlamlı derecede yüksek bulunmuştur ${ }^{23}$.

Araştırmaya katılan öğrencilerin SYBDÖ-2 toplam puanları kendisinde kronik hastalık olma durumuna göre incelendiğinde puan ortalamaları arasında fark görülmemiştir. Mustafa Kemal Üniversitesi'nde yapılan bir çalışmada da benzer şekilde fiziksel veya ruhsal hastalığa sahip olma durumuna göre SYBD-2 puan ortalamaları arasında anlamlı bir fark bulunamamışıı ${ }^{24}$.

Araştırmaya katılan öğrencilerin SYBDÖ-2 toplam puan ortalamaları beden kitle indeksine (BKi) göre karşılaştıııldığında istatistiksel olarak anlamlı bir fark saptanmamıştır. Ancak BKI 30'un üzerinde olan öğrencilerin ölçek puanı en düşüktür. Ankara'da bir sağlık ocağına ve belediyeye ait bir spor kompleksine başvuran 18 yaş ve üzeri kadınlarında yapılan bir çalışmada da BKI'ne göre SYBDÖ-2 puan ortalamaları arasında istatistiksel olarak anlamlı bir fark bulunamamıştı ${ }^{25}$. Ancak Pamukkale Üniversitesi'nde sağık çalışanları üzerinde yapılan bir çalışmada ise zayıf olanların SYBDÖ-2 puan ortalaması diğerlerinden istatistiksel olarak anlamlı derecede yüksek bulunmuştur ${ }^{26}$. Araştırmaya katılan erkek öğrencilerin SYBDÖ-2 alt boyutları öğün atlama durumu ve sosyoekonomik durum algısına göre değerlendirildiğinde "beslenme" boyutunda anlamlı bir fark görülmektedir; öğün atlamayanların ve sosyoekonomik durum algısı iyi olanların bu alt boyuttan yüksek puan aldığı saptanmıştır. Hitit Üniversitesi'nde hemşirelik öğrencilerini kapsayan bir araştırmada kızlarda, ailesi ile yaşayanlarda, algilanan ekonomik durumu iyi olanlarda ve sigara içmeyenlerde beslenme alt grubu puan ortalaması daha yüksek bulunmuştur $2^{7}$. Çukurova Üniversitesi'nde yapılan bir çalışmada ise kızlarda "beslenme" alt boyut puan ortalaması daha yüksek bulunmuştur ${ }^{23}$.

Araştırmaya katılan öğrencilerde SYDBÖ-2 alt grupları sosyoekonomik duruma göre değerlendirildiğinde alt boyutlardan "manevi gelişim" puanının sosyoekonomik durum algısı yüksek olanlarda daha yüksek olduğu belirlenmiştir. Bu fark istatistiksel olarak da anlamlıdır. Manisa’da bir aile sağlığı merkezinde 15-49 yaş arası kadınlar arasında yapılan bir çalışmada gelir durumu ile manevi gelişim alt boyutu puanı arasında istatistiksel açıdan anlamlı bir ilişki bulunmuş olup, gelir durumu yüksek olanlarda bu alt boyutun puan ortalaması daha yüksektir ${ }^{28}$.

Yapılan araştırmada SYBDÖ-2'nin alt boyut puanları cinsiyete göre incelendiğinde, "fiziksel aktivite" alt boyutu puanının erkek öğrencilerde kız öğrencilerden daha yüksek olduğu görülmüştür ve bu fark istatistiksel olarak da anlamlı bulunmuştur. Literatürde de bu durumu destekleyen birçok yayın bulmak mümkündür ${ }^{21,29-31}$. Kız öğrencilerin fiziksel aktivite yapmalarının önündeki engellerin gelecek çalışmalarda aydınlatılması ve bu konuda girişimler yapılması gerekmektedir.

Öğrencilerin \%71,7'sinin Hepatit A ve B aşısı yaptırma ile ilgili soruları yanıtladıkları belirlenmiştir. Grubun Yaklaşık \%30’u aşı yaptııı yaptırmadığını hatıılamadığını beyan etmiştir. Yanıt veren öğrencilerin de \%38,0'ı Hepatit A ya da B açısından eksik aşıı ya da aşısız olduğunu belirtmiştir. Fakülte yönetiminin öğrenciler stajlara geçmeden aşlanmasının sağlaması gerekmektedir. 


\section{Sonuçlar ve Öneriler}

Sonuç olarak tıp fakültesi öğrencilerinin sağlıklı yaşam davranışları orta düzeyde bulunmuştur. Cinsiyetin fiziksel aktivite, beslenme, diş fırçalama, bağışılanma, emniyet kemeri takma açısından farkılık oluşturduğu saptanmıştır. Sosyoekonomik durumun da sağıkıı yaşam davranışlarında belirleyici etkenler arasında olduğu görülmüştür. Bu sonuçlar doğrultusunda; Tıp Fakültesinde birinci sınıftan itibaren sağıklı yaşam biçimi davranışlarını geliştirmeye yönelik konuların, eğitim programları gözden geçirilerek zenginleştirilmesi; Tıp Fakültesi birinci sınıftan itibaren öğrencilerin sağıkı yaşam biçimi davranışlarının belirlenmesi konusunda araştırmalar yapılarak değerlendirilmesi, üniversite yönetimi ve öğrenci koordinatörlükleriyle iş birliği yapılarak gerekli müdahalelerin yapılması önerilebilir.

Klinik stajlara geçmeden aşılanma olanağı sağlanarak aşılanma yüzdelerinin iyileştirilmesi, konu ile ilgili gerekli eğitimlerin verilmesi; Öğün atlama sebepleri araştıılarak, okul yemeklerinin niteliğinin değerlendirilmesi ve yemek temin eden firmaya geri bildirim verilmesi, firmanın değiştirilmesi gibi ya da kantindeki olanakların genişletilmesi gibi çözümler üretilerek ana öğünlerin atlanmasının önüne geçilmesi; Kampüs içinde fiziksel aktivite olanaklarının genişletilmesi, tesis ve hizmetlerin artıııması ve teşvik edilmesi, belediyelerle işbirliği yapılarak gençlere spor alanları açılması;

Bu önlemler hayata geçirildikçe periyodik olarak SYBDÖ-2 kullanılarak öğrencilerin durumlarının belirlenmesi ve müdahalelerin katkısının değerlendirilmesi sağlanabilir.

Araştırmaya katılımları için fakülte öğrencilerine teşekkür ederiz.
Sakarya Tip Dergisi 2018;8(1):20-29

KöSE ve Ark. Dönem I,II,III Öğrencilerinde Sağılııı Yaşam Davranış̧ar Ve lilişkili Faktörlerin Incelenmesi 
1. Esin N. Sağılıklı yaşam biçimi davranışları ölçeğinin Türkçeye uyarlanmaSı. Hemşirelik Bülteni 1997;12: 87-95.

2. Ferguson KJ. Health behaviour. Wallace RB. Public Health\& Preventive Medicine. 14. Basım Stanford: Appleton\&Lange, 1998 p. 811-816.

3. Zaybak A, Fadıloğlu Ç. Üniversite öğrencilerinin sağlı̆ı geliştirme davranışı ve bu davranışı etkileyen etmenlerin belirlenmesi. Ege Üniversites Hemșirelik Yüksekokulu Dergisi 2004;20: 77-95.

Sakarya Tıp Dergisi 2018;8(1):20-29

4. Ayaz S, Tezcan S, Akıncı F. Hemşirelik yüksekokulu öğrencilerinin sağlı ğı geliştirme davranışları. Cumhuriyet Üniversitesi Hemşirelik Yüksekokulu Dergisi 2005;9: 26-34.

5. Pasinlioğlu $T$, Gözüm S. Birinci basamak sağlık hizmetlerinde çalışan sağlık personelinin sağılk davranışları. Cumhuriyet Üniversitesi Hemşirelik Yüksekokulu Dergisi 1998;2: 60-68.

6. Walker SN, Volkan K. Sechrist KR, Pender NJ. Health promoting lifest yles of older adults: comparisons with young and middle aged adults, correlates and patterns. Advances in Nursing Science, 1988; 11: 76 89.

7. Walker SN, Hill-Polerecky DM. Psychometric evaluation of the health promoting lifestyle profile II. Unpublished manuscript, University of Nebraska Medical Center, 1996. http://app1.unmc.edu/Nursing/ conweb/HPLPII_Abstract_. Erişim tarihi: 02.10.2017.

8. Bahar Z, Besşer A, Gördes N, Ersin F, Kırsal A. Sağlıklı yaşama biçimi davranışları ölçeği II'nin geçerlik güvenirlik çalışması, CÜ. Hemşirelik Yüksekokulu Dergisi 2008;12: 1-13.

9. Çelik GO, Malak AT, Bektaş M, Yılmaz D, Yümer AS, Öztürk Z, Demir E. Sağlık yüksekokulu öğrencilerinin sağlı̆ı geliştirme davranışlarını etkileyen etmenlerin incelenmesi. Anatolian Journal of Clinical Investigation 2009; 3: 164-169.

10.Ünalan D, Şenol V, Öztürk A, Erkorkmaz Ü. Meslek yüksekokullarının sağlık ve sosyal programlarında öğrenim gören öğrencilerin sağlıklı yaşam biçimi davranışları ve öz-bakım gücü düzeyleri arasındaki ilişkinin incelenmesi. i.ü. Tıp Fakültesi Dergisi 2007; 14:101-109.

11. Ertop NG, Yılmaz A, Erdem YÖ. Üniversite öğrencilerinin sağlıkı yaşam biçimleri. KÜ Tip Fak Derg 2012; 14:1-7.

12. Cürcani $M$, Tan M, Özdelikara A. Hemşirelerin sağlıklı yaşam biçimi dav ranışları ve etkileyen faktörlerin belirlenmesi. TAF Preventive Medicine Bulletin 2010; 9: 487-492.

13. Özkan S, Yılmaz E. Hastanede çalışan hemşirelerin sağlıklı yaşam biçimi davranışları. Fırat Sağlık Hizmetleri Dergisi, 2008;3: 89-96.

14.Beydağ KD, Uğur E, Sonakın UC, Yürügen B. Sağlık ve yaşam dersinin üniversite öğrencilerinin sağıklı yaşam biçimi davranışlarına etkisi. Gümüşhane Üniversitesi Sağık Bilimleri Dergisi /Gümüşhane University Journal of Health Sciences 2014;3: 599-609.

15. Güner ic, Demir F. Ameliyathane hemşirelerinin sağııkı yaşam biçimi davranıșlarının belirlenmesi. Atatürk Üniversitesi Hemșirelik Yüksekokulu Dergisi 2016;9: 17-25.

16. Karadeniz G, Uçum YE, Dedeli Ö, Karaağaç Ö. Üniversite öğrencilerinin sağlıklı yaşam biçimi davranışları. TAF Preventive Medicine Bulletin 2008; 7: 497-502.

17. İhan N, Batmaz M, Akhan LU. Üniversite öğrencilerinin sağııkı yaşam biçimi davranışları. Maltepe Üniversitesi Hemşirelik Bilim ve Sanatı Dergisi 2010; 3: 34-44

18. Özyazıcıoğlu N, Kilıç M, Erdem N, Yavuz C, Afacan S. Hemşirelik öğrencilerinin sağılıkı yaşam biçimi davranışlarının belirlenmesi. Uluslararas İnsan Bilimleri Dergisi 2011;8: 277-332.

19. Tambağ H. Hatay sağılk yüksekokulu öğrencilerinin sağlıklı yaşam biçimi davranışları ve etkileyen faktörler. Sağlık Bilimleri Fakültesi Hemşirelik Dergisi 2011;18: 47-58.

20. Karadeniz G, Uçum EY, Dedeli Ö, Karaağaç Ö. Üniversite öğrencilerinin sağlıklı yaşam biçimi davranışları. TAF Preventive Medicine Bulletin 2008; 7: 497-502.

21. Yıldııım N. Üniversite öğrencilerinin bazı sosyo-demografik özelliklerinin sağlıkıı yaşam biçimi davranışlarına etkisi. Yüksek Lisans Tezi, Cumhuriyet Üniversitesi, Sivas, 2005.

22. Şimşek H, Öztoprak D, îkizoğlu E, Safalı F, Yavuz Ö, Onur Ö, Tekel Ş, Çiftçi Ş. Dokuz eylül üniversitesi tıp fakültesi öğrencilerinde sağılkı yaşam biçimi davranışları ve ilişkili etmenler. DEÜ Tıp Fakültesi Dergisi, 2012;26:151-157

23. Çukurova üniversitesi sağık bilimleri öğrencilerinin sağıklı yașam biçimi davranışların değerlendirilmesi, Bozhüyük Aile hekimliği uzmanlık tezi. Tez danışmanı: Sevgi Özcan Adana (2010) İnternet::http://library. cu.edu.tr/tezler/8018.pdf (Erişim tarihi: 10.05.2017)

24. Kaya M, Özvarış ŞB, Atlas H, Altay M, Atik Ç, Aytekin G, Badak E. Ankara'da bir sağlık ocağına ve belediyeye ait bir spor kompleksine başvuran 18 yaş ve üzeri kadınların sağlığı geliştirici yaşam biçim dü- zeylerinin belirlenmesi. Toplum Hekimliği Bülteni 2009;28: 8-13.

25. Açıksöz S, Uzun Ş, Arslan F. Hemşirelik öğrencilerinin sağık algısı ile sağlığı geliştirme davranışları arasındaki ilişkinin incelenmesi. Gülhane Tıp Dergisi 2013; 55: 181-187.

26. Yalçınkaya M, Özer FG, Karamanoğlu AY. Sağlık çalışanlarında sağlıklı yaşam biçimi davranışlarının değerlendirilmesi. TSK Koruyucu Hekimlik Bülteni, 2007;6: 409-420.

27. Yılmazel G, Çetinkaya F, Naçar M. Hemşirelik Öğrencilerinde Sağlı̆ı Geliştirme Davranışları. TAF Preventive Medicine Bulletin, 2013;12: 261-270;

28. Altıparmak S, Kutlu AK. 15-49 yaş grubu kadınlarda sağlığı geliştirme davranışları ve etkileyen faktörlerYaş Grubu Kadınlarda Sağlığı Geliştirme Davranışları ve Etkileyen Faktörler. [The healthy lifestyle behaviors of 15-49 age group women and affecting factors]. TAF Preventive Medicine Bulletin 2009; 8: 421-426.

29.Diez SMU, Perez-Fortis A. Socio-demographic predictors of health behaviors in Mexican college students. Health Promot Int (Electronic Journal) 2009; October http://heapro.oxfordjournals.org/. Erişim tarihi: 08.05.2017.

30.Lee RLT, Loke AJTY. Health-promoting behaviors and psychosocial well-being of university students in Hong Kong. Public Health Nursing 2005; 22: 209-220.

31.Savcı S, Öztürk M, Arıkan H, İnce Di, Tokgözoğlu L. Üniversite öğrencilerinin fiziksel aktivite düzeyleri. Türk Kardiyoloji Derneği Arşivi 2006; 34: 166-172. 